\title{
Faktor Keputusan Pembelian Konsumen Online Marketplace Indonesia
}

\author{
William $^{1 *}$, Heru Wijayanto Aripradono ${ }^{2}$ \\ ${ }^{1}$ Program Studi Entrepreneurship, Universitas Surya, Bogor, Jawa Barat \\ ${ }^{2}$ Program Studi Teknik Informatika, Universitas Internasional Batam, Kepulauan Riau \\ Email: ${ }^{1 *}$ williammalino@ outlook.com, ${ }^{2}$ heru.wijayanto@uib.ac.id
}

(Naskah masuk: 7 April 2020, direvisi: 11 Mei 2020, diterima: 19 Mei 2020)

\begin{abstract}
Abstrak
Studi tentang faktor yang mempengaruhi keputusan pembelian konsumen online di online marketplace dilakukan untuk mengukur bagaimana dampak faktor tersebut terhadap keputusan pembelian konsumen. Tujuan dari studi ini adalah untuk mengetahui signifikansi dari elemen-elemen pembentuk keputusan pembelian konsumen yang mencakup logistik digital, integritas online, desain website, pemasaran digital, dan alternatif kontak merek/vendor. Penelitian ini akan menggunakan metode kuantitatif dikarenakan penelitian ini berupaya untuk menguji hipotesis terkait suatu fenomena dengan mengetahui hubungan dari faktor-faktor online marketplace apa saja yang memengaruhi keputusan pembelian konsumen online. Teknik yang digunakan dalam studi ini adalah regresi berganda. Analisis Regresi Berganda digunakan untuk mengetahui seberapa besar pengaruh variabel bebas yaitu: Logistik Digital (X1), Pemasaran Digital (X2), Integritas Online (X3), Alternatif Kontak Vendor/Merek (X4), dan Desain Website (X5) terhadap variabel terikat yaitu, keputusan pembelian konsumen online (Y). Hasil pengolahan data menunjukkan dari lima variabel bebas yang diteliti, hanya variabel Integritas Online yang memiliki pengaruh signifikan terhadap variabel terikat Keputusan Pembelian Konsumen Online. Faktor yang paling dominan di dalam penelitian ini terkait Integritas Online adalah jaminan keamanan dalam transaksi dan pilihan alternatif pembayaran yang beragam, dimana $>90 \%$ responden mengatakan setuju dan sangat setuju bahwa kedua faktor tersebut merupakan faktor yang penting dalam mempengaruhi keputusan pembelian konsumen secara online.
\end{abstract}

Kata Kunci: Keputusan Pembelian Konsumen Online, Logistik Digital, Integritas Online, Desain Website, Pemasaran Digital, Alternatif Kontak

\section{Factors of Consumer Purchasing Decisions at Indonesian Online Marketplace}

\begin{abstract}
The study of factors that influence online consumer purchasing decisions in the online marketplace is carried out to measure how these factors impact consumer purchasing decisions. The purpose of this study is to determine the significance of the elements forming consumer purchasing decisions that include digital logistics, online integrity, website design, digital marketing, and alternative brand/vendor contacts. This research will use quantitative methods because this research seeks to hypotheses test related to a phenomenon by knowing the relationship of any factors - online marketplace factors that influence online consumer purchasing decisions. The technique used in this study is multiple regression. Multiple Regression Analysis is used to find out how much influence the independent variables are: Digital Logistics (X1), Digital Marketing (X2), Online Integrity (X3), Alternative Vendor/Brand Contacts (X4), and Website Design (X5) on the dependent variable namely, online consumer purchasing decisions $(Y)$. The results of data processing showed that of the five independent variables studied, only the Online Integrity variable had a significant influence on the dependent variable of Online Consumer Purchasing Decisions. The most dominant factor in this research related to Online Integrity is security guarantee in transactions and various alternative payment options, where $>90 \%$ of respondents said agree and strongly agree that these two factors are important factors in influencing consumer purchasing decisions online.
\end{abstract}

Keywords: Online Consumer Purchasing Decisions, Digital Logistics, Online Integrity, Website Design, Digital Marketing, Alternative Contacts. 


\section{PENDAhUluan}

Pada tahun 2016, industri e-commerce secara global mengalami pertumbuhan, dikarenakan penetrasi teknologi, khususnya internet yang merupakan tulang punggung dari ekonomi digital, mengalami perkembangan disruptive secara eksponensial, yang kemudian menjadi enabler untuk mentransformasi bisnis e-commerce [1]. Berdasarkan aktivitas e-commerce secara global, di awal tahun 2020, sebanyak $74 \%$ melakukan pembelian secara online dengan menggunakan berbagai macam perangkat [2].

Pertumbuhan e-commerce secara global turut serta ditopang oleh pertumbuhan e-commerce di Indonesia, yang telah muncul sejak tahun 2014 sebagai pasar e-commerce terbesar di ASEAN dengan penjualan online sebesar US \$1,1 miliar [3]. Jumlah tersebut diprediksi akan terus meningkat. Pada akhir tahun 2020 diproyeksikan pendapatan dari penjualan online adalah sebesar US \$26,922 miliar [4].

Meningkatnya potensi penjualan online secara lebih lanjut mendorong valuasi pasar e-commerce di Indonesia, yang mengalami peningkatan sebesar 31,3\% dari tahun 2016 hingga tahun 2019 dengan alasan: kondisi demografis, pertumbuhan ekonomi, tingginya tingkat adopsi telepon pintar, dan semakin banyaknya perusahaan e-commerce yang menawarkan produk-produk berbeda dengan perusahaan lain yang sejenis [5].

Terdapat 3 faktor penting yang mendukung ekosistem $e$ commerce dapat berjalan, yaitu sistem pembayaran digital yang aman, infrastruktur, dan pemasaran digital. Salah satu isu utama yang perlu diperhatikan agar valuasi dari e-commerce dapat meningkat sesuai dengan prediksi adalah dukungan infrastruktur, khususnya untuk yang berada di luar Pulau Jawa, dimana saat ini $65 \%$ pengguna internet terdapat di Pulau Jawa terutama Jakarta, dengan $43 \%$ penetrasi pengguna internet nasional di tahun 2016 [3].

Penetrasi transaksi online di Indonesia pada awal tahun 2020 mencapai sekitar lebih dari $93 \%$ pengguna internet melakukan pencarian secara online untuk produk ataupun jasa yang akan dibelinya. Tiga kategori terbesar dalam pengeluaran belanja online adalah Fashion and Beauty (US \$ 4,79 miliar), Electronics and Physical Media (US \$ 4,73 miliar) dan Food and Personal Care (US \$3,73 miliar) [2]. Data ini menunjukkan besarnya pangsa pasar Indonesia, khususnya dalam hal aktivitas belanja online.

Berkembangnya industri e-commerce memberikan kesempatan kepada SME's (Small Medium Enterprises) dan LSE (Large Scale Enterprises) untuk dapat mengadopsi dan memanfaatkan media e-commerce untuk mengembangkan bisnisnya [6]. Berbagai faktor yang memengaruhi e-commerce telah diteliti, dimana kepercayaan dan loyalitas digital menjadi salah satu yang paling menonjol sebagai pendorong keputusan pembelian konsumen [7].

Sejak awal mula berkembangnya budaya transaksi secara online, kepercayaan terhadap e-commerce dan vendor/merek telah dianggap vital untuk mampu menarik kepercayaan konsumen dalam mengeluarkan uangnya di internet [8]. Penelitian ini kemudian berkembang dimana ketika konsumen tidak mengenal vendor/merek dari suatu website, maka kemungkinan besar konsumen tidak akan percaya dengan website tersebut. Dampaknya adalah konsumen akan cenderung tidak tertarik dengan isi dari website tersebut dan semakin kecil kemungkinan melakukan pembelian produk di sana. Kondisi ini umumnya terjadi di perusahaan start-up dimana perusahaan belum terlalu dikenal dan/atau perusahaan memasuki pasar baru [9].

Kim melakukan penelitian tentang e-commerce dengan mengambil sudut pandang yang lebih luas, dimana fokus yang diambil tidak hanya mengenai isu kepercayaan dan keamanan, melainkan lebih kepada atribut atau faktor yang terpenting dari sudut pandang konsumen ketika memilih suatu vendor/merek atau website. Hasilnya ditemukan 4 faktor atribut belanja online yang dianggap penting untuk diukur, yaitu: transaksi/biaya, program insentif, desain website, dan interaktivitas [10].

Berbagai atribut yang berfokus kepada kepercayaan dan faktor terpenting dari sudut pandang konsumen dalam menentukan pembelian, kemudian terus berkembang dan dijadikan acuan diberbagai penelitian lainnya, hingga akhirnya menjadi faktor-faktor atribut baru [11], yang terdiri dari :

a. Logistik Digital dan implikasi dari strategi harga pengiriman, isu lingkungan, efisiensi, dan kebijakan pembatalan atau pengembalian produk [12]-[14].

b. Integritas Online untuk konsumen merupakan salah satu komponen penting yang harus disediakan oleh vendor/merek, seperti: keamanan informasi, kebijakan pengambilan data, dan metode pembayaran [15]-[17].

c. Desain Website, dimana studi menunjukkan bahwa menciptakan website yang terpercaya dapat meningkatkan penjualan [7], [18], [19].

d. Pemasaran Digital juga merupakan salah satu faktor penentu dalam menarik konsumen memilih vendor/website. Pemasaran Digital merupakan strategi pemasaran dengan menggunakan media internet [20], [21].

e. Alternatif Kontak Vendor/Merek juga merupakan salah satu faktor penting untuk konsumen digital dimana dapat menciptakan kepercayaan dan juga loyalitas. Berbagai bentuk dari alternatif kontak dapat berdampak kepada keputusan pembelian konsumen [22], [23].

Pemahaman akan faktor-faktor yang berdampak positif terhadap keputusan pembelian konsumen online, khususnya $e$ commerce dapat menjadi acuan bagi vendor/merek, terlebih karena persaingan e-commerce yang ketat dimana kepercayaan dan bagaimana mengalokasikan kepercayaan yang dibangun tersebut menjadi faktor yang penting[24].

Konsep bisnis online marketplace adalah model bisnis dengan menerapkan skema $\mathrm{C} 2 \mathrm{C}$ (Consumer to Consumer)/P2P (People to People) dimana vendor/merek menyediakan platform untuk masyarakat yang ingin berjualan online dengan membantu mempertemukan antara penjual dengan pembeli. Adapun, kegiatan transaksi bisnis (pembelian, penjualan, pemesanan, dan pengiklanan) dilakukan dengan media elektronik menggunakan internet sebagai media [25].

Menurut penelitian Forrester di tahun 2016, secara global, 53\% konsumen yang melakukan transaksi online melakukan transaksinya di online marketplace, dengan 27\% konsumen 
melakukan pembelian di lebih dari 3 online marketplace berbeda dimana satu produk sejenis dijual oleh banyak penjual. Luasnya varian produk serta kemudahan yang ditawarkan oleh online marketplace menjadi kunci utama mengapa konsumen memilih untuk berbelanja online di platform tersebut [26].

Di Indonesia, tren dari online marketplace terus mengalami peningkatan, dimana pada Januari 2018 terus terjadi peningkatan dari sisi pencarian produk secara online sebesar $45 \%$, kunjungan ke platform sebesar $45 \%$, dan pembelian produk sebesar $40 \%$ jika dibandingkan dengan tahun 2017 di bulan Januari [27].

Dalam ekosistem online marketplace terdapat 5 komponen penting agar online marketplace dapat beroperasi dengan maksimal, yaitu: infrastruktur logistik (logistik digital), sistem pembayaran yang aman (integritas online), pemasaran digital, pembeli, dan penjual; dimana terdapat pula pengaruh desain website dan alternatif kontak vendor/merek yang mendorong konsumen, baik pembeli atau penjual memutuskan untuk menggunakan suatu platform, selain pemasaran digital [28].

\section{A. Logistik Digital}

Oleh karena transaksi dilakukan secara otomatis dan digital; dari tahap pencarian produk, penempatan produk belanjaan, hingga pilihan pembayaran; membuat pergerakan informasi menjadi jauh lebih cepat jika dibandingkan dengan transaksi bisnis konvensional. Hal ini membuat sistem logistik harus menyesuaikan dengan sistem yang lebih cepat dan terintegrasi agar dapat memenuhi kebutuhan pasar [28].

\section{B. Integritas Online}

Integritas Online merupakan salah satu faktor yang penting dalam memunculkan keinginan konsumen untuk menggunakan layanan online marketplace. Bagi vendor/merek, keamanan digital adalah isu yang penting untuk membangun kepercayaan antara penjual dengan pembeli. Sebagai vendor/merek, keamanan dalam mengelola informasi menjadi isu utama dikarenakan vendor/merek akan menghadapi data personal dan data transaksi yang beresiko untuk disalahgunakan oleh pihak tidak bertanggung jawab [28].

Kondisi terkait kepercayaan masyarakat Indonesia terhadap pembayaran sistem digital masih cukup rendah. Fakta menunjukkan bahwa di Indonesia terdapat $48 \%$ orang yang memiliki akun bank dan penetrasi kartu kredit hanya sebesar $2,4 \%$ [2] dengan penyebab utamanya adalah sebagian masyarakat belum mempercayai keamanan sistem perbankan di Indonesia. Hal ini tentu menjadi masalah mengingat sistem pembayaran melalui perbankan merupakan salah satu pilar utama dari e-commerce.

\section{Desain Website}

Menciptakan tampilan website yang menarik penting dilakukan oleh vendor/merek untuk menarik perhatian konsumen di pasar. Desain merupakan elemen utama dari website, termasuk di dalamnya faktor seperti: presentasi, gambar, model, bahan, pencahayaan, desain grafis, dan informasi. Desain dari website ditujukan juga untuk membangun kepercayaan, kepuasan, dan loyalitas [18].

\section{Alternatif Kontak Vendor/Merek}

Agar dapat menarik konsumen (penjual dan pembeli), kemudahan dalam menghubungi vendor/merek penting untuk dilakukan, dikarenakan tingkat literasi penjual di Indonesia masih rendah terhadap digital. Dari sisi pembeli hambatannya adalah tingkat kepercayaan diri terhadap online marketplace masih rendah, sehingga keberagaman cara konsumen menghubungi perusahaan dapat membantu baik pembeli maupun penjual lebih cepat beradaptasi dengan digital [29].

\section{E. Pemasaran Digital}

Perkembangan dunia IT, internet, media, dan komunikasi telah mengubah dasar dari bisnis dan kegiatan pemasaran dengan terbukanya bentuk baru, yaitu channel elektronik. Pemasaran digital dengan penggunaan data dan aplikasi elektronik untuk merencanakan dan mengeksekusi suatu konsep, distribusi dan penetapan harga dari ide, produk, dan jasa untuk menciptakan pertukaran yang memuaskan individu dan juga tujuan organisasi [30].

Kelima faktor yang telah diutarakan di atas merupakan faktor-faktor yang dapat mendorong konsumen melakukan pengambilan keputusan untuk berbelanja secara online di online marketplace. Menurut Engel-Kollat-Blackwell Model (EKB) Secara umum, keputusan pembelian konsumen dibagi menjadi 5 tahapan. Perilaku konsumen merupakan salah satu kerangka pemikiran yang dapat diaplikasikan dalam proses pengambilan keputusan konsumen di e-commerce yaitu [31]:

- Menyadari adanya masalah/kebutuhan

- Mencari informasi

- Evaluasi dari alternatif

- Menentukan pilihan

- Evaluasi dari pilihan

Proses pengambilan keputusan konsumen untuk melakukan pembelian online dimulai dengan kesadaran konsumen akan kebutuhan suatu produk, lalu konsumen mempertimbangkan untuk melakukan pembelian secara online dan mulai mencari informasi terkait produk tersebut serta mencari alternatif produk yang tersedia. Konsumen kemudian melakukan pembelian untuk produk yang sesuai dengan kebutuhan konsumen. Sebelum melakukan pembelian, konsumen akan dihadapkan pada faktor-faktor yang membatasi atau memengaruhi keputusan pembelian tersebut [32].

Proses pengambilan keputusan konsumen juga turut terpengaruh seiring dengan penetrasi internet, dimana konsumen semakin dimudahkan jika dibandingkan dengan ketika berbelanja secara tradisional, dimulai dari tahap mencari informasi produk yang dapat dilakukan dari mana saja, bentuk visualisasi yang beragam, hingga proses evaluasi produk yang dapat dilakukan dimana saja dan kapan saja dengan cara diskusi antar konsumen atau konsumen dengan penjual [33].

Penting bagi perusahaan untuk memahami faktor mana yang harus diprioritaskan oleh perusahaan agar dapat memiliki 
daya saing yang lebih baik dalam menarik konsumen dan membuat konsumen menjadi lebih loyal terhadap perusahaan.

Berdasarkan latar belakang yang ada di atas, maka rumusan masalah untuk penelitian ini adalah sebagai berikut :

a. Apakah logistik digital memiliki pengaruh positif terhadap keputusan pembelian konsumen?

b. Apakah pemasaran digital memiliki pengaruh positif terhadap keputusan pembelian konsumen?

c. Apakah integritas online memiliki pengaruh positif terhadap keputusan pembelian konsumen?

d. Apakah alternatif kontak vendor/merek memiliki pengaruh positif terhadap keputusan pembelian konsumen?

e. Apakah desain website memiliki pengaruh positif terhadap keputusan pembelian konsumen?

\section{METODOLOGI PENELITIAN}

Penelitian ini akan menggunakan metode kuantitatif dikarenakan penelitian ini berupaya untuk menguji hipotesis terkait suatu fenomena dengan mengetahui hubungan dari faktor-faktor online marketplace apa saja yang memengaruhi keputusan pembelian konsumen online.

Berdasarkan karakteristik masalah, penelitian ini termasuk ke dalam penelitian asosiatif kausal dimana penelitian ini ditujukan untuk mengungkapkan permasalahan yang bersifat hubungan sebab akibat antara dua variabel atau lebih. Pada penelitian ini digunakan variabel bebas dan variabel terikat.

Pola penafsiran yang akan digunakan di dalam penelitian ini adalah deduktif dikarenakan peneliti akan menurunkan beberapa hipotesis dan kebenaran hipotesis yang diturunkan tersebut dapat dikaji lewat teori kebenaran koherensi apakah diterima atau ditolak [34]. Penelitian deduktif merepresentasikan persepsi umum dari hubungan antara teori dengan praktik di dalam penelitian [35].

Melalui pemahaman teori dari penelitian sebelumnya dan literatur di bidang tertentu, peneliti telah mendeduksikan satu atau lebih hipotesis yang akan dioperasionalisasikan dengan menentukan bagaimana data akan dikumpulkan berkaitan dengan teori dan model penelitian dimana hipotesis didapatkan dari deduksi. Ketika proses pengumpulan data telah selesai, temuan tersebut akan diukur dengan hipotesa, sehingga peneliti dapat menentukan apakah hipotesis diterima atau ditolak. Tahap terakhir adalah memberikan rekomendasi kepada teori dibalik penelitian [35].

Metode kuantitatif cenderung menerapkan pendekatan deduktif ketika melihat hubungan antara teori dengan praktik dari suatu penelitian ketika ingin menguji suatu teori [35]. Variabel penelitian adalah suatu atribut atau sifat atau nilai dari orang, objek, maupun kegiatan yang memiliki variasi tertentu yang telah ditetapkan oleh peneliti untuk dipelajari dan kemudian dapat ditarik simpulannya.

Variabel Terikat adalah variabel yang dipengaruhi atau dapat juga dikatakan sebagai akibat adanya variabel bebas. Variabel terikat di dalam penelitian ini adalah keputusan pembelian konsumen online.

Variabel Bebas adalah variabel yang mempengaruhi atau dapat juga dikatakan menjadi sebab perubahan atau timbulnya variabel terikat. Variabel bebas di dalam penelitian adalah bauran pemasaran yang terdiri dari 5 dimensi, yaitu:

a. Logistik Digital

b. Pemasaran Digital

c. Desain Website

d. Alternatif Kontak Vendor/Merek

e. Integritas Online

Penelitian ini akan menggunakan kuesioner sebagai metode pengumpulan data. Kuesioner merupakan daftar pertanyaan yang digunakan oleh peneliti untuk dapat memperoleh data dari narasumber baik melalui proses komunikasi maupun dengan mengajukan pertanyaan. Kuesioner di dalam penelitian ini akan menggunakan model pertanyaan tertutup, dengan menggunakan skala likert. Skala likert digunakan agar dapat melakukan pengukuran sikap akan suatu fenomena.

Adapun, yang akan menjadi responden di dalam penelitian ini adalah:

a. Konsumen belanja online yang berusia 18-44 tahun (prioritas utama adalah mereka yang berusia 20-34 tahun karena konsumen berusia 20-34 tahun adalah konsumen utama dari online marketplace) dan berdomisili di Indonesia.

b. Konsumen belanja online diartikan sebagai orang yang setidaknya melakukan transaksi pembelian secara online minimal $1 \mathrm{x}$ dalam kurun waktu 3 bulan melalui online marketplace di tahun 2019 (Oktober-Desember 2019).

c. Konsumen belanja online yang merupakan responden adalah konsumen yang setidaknya memiliki pemahaman terkait vendor/merek online marketplace di Indonesia.

d. Penelitian ini tidak berfokus/spesifik pada salah satu vendor online marketplace, namun online marketplace secara umum.

Cara yang dilakukan untuk melakukan penentuan jumlah sampel adalah regresi berganda, sehingga ukuran sampel sebaiknya adalah 10x dari jumlah variabel dalam penelitian. Pada penelitian ini terdapat 6 variabel, maka setidaknya jumlah responden di dalam penelitian ini berjumlah 60 orang, berada dalam rentang yang dapat ditoleransi dikarenakan rentang yang ideal adalah 30-500 responden. Untuk menentukan ukuran sampel dari suatu populasi yang tidak diketahui setidaknya dibutuhkan lebih dari 30 orang responden dan untuk survei bisnis sampel sekitar 100 orang sudah dianggap memadai. Penelitian ini akan menggunakan sampel 100 orang responden, dimana telah memenuhi kriteria [36].

Pengambilan sampel ini akan menggunakan teknik pengambilan sampel purposive sampling, yaitu pengambilan sampel yang dilakukan dengan adanya kriteria-kriteria tertentu. Analisis di dalam penelitian ini akan menggunakan alat bantu SPSS (Statistical Package for Social Science) untuk dapat menguji hipotesis yang dimiliki. Adapun, proses pengolahan data akan melalui beberapa tahapan.

\section{A. Uji Validitas}

Uji Validitas merupakan uji untuk mengetahui kemampuan suatu instrumen (alat pengukur) dalam melakukan pengukuran kepada apa yang harus diukur. Pada 
penelitian ini, digunakan tingkat pengukuran validitas dengan cara membandingkan nilai $\mathrm{r}$ hitung (correlation item total correlation) dengan nilai $\mathrm{r}$ table untuk degree of freedom $(\mathrm{df})$ $=\mathrm{n}-\mathrm{k}$, dimana $\mathrm{n}$ adalah jumlah sampel dan $\mathrm{k}$ adalah jumlah variabel bebas. Bila $r$ hitung $>r$ tabel, berarti pernyataan tersebut dinyatakan valid. Bila $r$ hitung $<r$ tabel, berarti pernyataan tersebut dinyatakan tidak valid.

\section{B. Uji Reliabilitas}

Uji Reliabilitas merupakan uji untuk menguji tingkat kepercayaan suatu instrumen dapat digunakan secara berulang dan dapat memberikan hasil ukur yang sama. Pada penelitian ini uji reliabilitas dilakukan dengan menguji instrumen sebanyak satu kali menggunakan uji statistic Cronbach Alpha. Suatu instrumen dinyatakan handal jika nilai Cronbach Alpha lebih besar dari 0,6, namun tidak lebih besar dari 0,75.

\section{Uji Asumsi Klasik}

Uji Asumsi Klasik digunakan untuk mengetahui kondisi data yang dipergunakan dalam penelitian yang dilakukan agar diperoleh model analisis yang tepat. Penelitian ini menggunakan empat pengujian asumsi klasik yaitu uji multikolinearitas, heterokedastisitas, autokorelasi dan normalitas.

\section{Analisa Regresi Berganda}

Analisis Regresi Berganda digunakan untuk mengetahui seberapa besar pengaruh variabel bebas. Bentuk regresi linier berganda yang digunakan dalam penelitian ini adalah sebagai berikut:

$$
\mathrm{Y}=\mathrm{a}+\mathrm{b} 1 \mathrm{X} 1+\mathrm{b} 2 \mathrm{X} 2+\mathrm{b} 3 \mathrm{X} 3+\mathrm{b} 4 \mathrm{X} 4+\mathrm{b} 5 \mathrm{X} 5+\mathrm{e}
$$

$$
\begin{aligned}
& \text { Keterangan: } \\
& \mathrm{Y}=\text { Keputusan Pembelian Konsumen Online } \\
& \mathrm{A}=\text { Konstanta } \\
& \text { b1, b2, b3, b4, b5 = Koefisien regresi } \\
& \mathrm{X} 1=\text { Logistik Digital } \\
& \mathrm{X} 2=\text { Integritas Online } \\
& \mathrm{X} 3 \quad=\text { Desain Website } \\
& \text { X4 = Pemasaran Digital } \\
& \text { X5 = Alternatif Kontak Vendor/Merek } \\
& \text { e }=\text { Error }
\end{aligned}
$$

\section{E. Analisa R-Squared}

Analisis $R$-squared $\left(\mathrm{R}^{2}\right) /$ Koefisien Determinasi dilakukan untuk mengukur seberapa jauh kemampuan model dalam menerangkan variasi dari variabel terikat. Nilai koefisien determinasi berada di antara 0 hingga 1 . Nilai koefisien determinasi yang kecil menunjukkan bahwa kemampuan variabel-variabel bebas dalam menjelaskan variabel terikat terbatas. Sebaliknya, jika nilai koefisien determinasi mendekati 1, berarti variabel-variabel bebas memberikan kelengkapan informasi yang dibutuhkan untuk memprediksi variabel terikat.

\section{F. Uji Kelayakan Model (Uji F)}

Uji $\mathrm{F}$ bertujuan untuk menunjukan apakah semua variabel bebas yang dimasukkan ke dalam model secara simultan atau bersama-sama mempunyai pengaruh terhadap variabel terikat.

\section{G. Uji Pengaruh Kausalitas (Uji T)}

Uji Pengaruh Kausalitas (Uji T) digunakan untuk menunjukan apakah suatu variabel bebas secara individual mempengaruhi varibel terikat. Hipotesis yang dipakai adalah sebagai berikut:

$\mathrm{HO}: \mathrm{bi}=0$, artinya suatu variabel bebas tidak berpengaruh terhadap variabel terikat.

Ha : bi > 0, artinya suatu variabel bebas berpengaruh positif terhadap variabel terikat.

Kriteria pengujian dengan tingkat signifikansi $(\alpha)=0.05$ ditentukan sebagai berikut:

Apabila t hitung < t tabel, maka $\mathrm{H} 0$ ditolak dan Ha diterima. Apabila $\mathrm{t}$ hitung $>\mathrm{t}$ tabel, maka H0 diterima dan Ha ditolak.

\section{ANALISIS DAN PEMBAHASAN}

Jumlah responden di dalam penelitian ini adalah 100 orang. Berdasarkan data primer yang didapatkan melalui kuesioner, maka hasil sebaran responden berdasarkan jenis kelamin pada penelitian ini adalah $46 \%$ pria dan $54 \%$ wanita. Karakteristik responden berdasarkan rentang usia didominasi oleh kelompok usia 21-25 tahun, secara lengkap dapat dilihat pada tabel 1 .

Tabel 1. Karakteristik Responden Berdsarkan Rentang Usia

\begin{tabular}{crr}
\hline $\begin{array}{c}\text { Kelompok } \\
\text { Usia }\end{array}$ & Jumlah & Persentase \\
\hline $16-20$ & 9 & $9 \%$ \\
\hline $21-25$ & 80 & $80 \%$ \\
\hline $26-30$ & 8 & $8 \%$ \\
\hline $31-35$ & 1 & $1 \%$ \\
\hline$>40$ & 2 & $2 \%$ \\
\hline Total & $\mathbf{1 0 0}$ & $\mathbf{1 0 0 \%}$ \\
\hline
\end{tabular}

Berdasarkan hasil uji validitas, keseluruhan butir pernyataan memiliki $r$ hitung yang lebih tinggi jika dibandingkan dengan $r$ tabel. Oleh karena itu, dapat ditarik simpulan bahwa butir indikator yang digunakan di dalam penelitian ini telah berhasil melewati uji validitas. Sedangkan hasil pengujian reliabilitas memiliki Cronbach Alpha lebih besar dari 0,6 dengan rata-rata keseluruhan sebesar 0,739, maka dapat ditarik simpulan bahwa keseluruhan variabel di dalam penelitian ini dapat diandalkan. Dapat diandalkan berarti kuesioner dapat dikatakan konsisten apabila digunakan untuk mengukur gejala yang sama di tempat yang lain. 
Tabel 2. Hasil Uji Regresi Linear Berganda

\begin{tabular}{crrrrr}
\hline Variabel & \multicolumn{2}{c}{$\begin{array}{l}\text { Unstandarized } \\
\text { Coefficientets }\end{array}$} & $\begin{array}{c}\text { Standarized } \\
\text { Coefficients }\end{array}$ & $\mathbf{t}$ & Sig \\
\hline & $\mathbf{B}$ & $\begin{array}{c}\text { Std. } \\
\text { Error }\end{array}$ & Beta & & \\
\hline (Constant $)$ & 2,219 & 0,995 & & 2,229 & 0,028 \\
\hline $\mathbf{X 1}$ & 0,092 & 0,118 & 0,085 & 0,784 & 0,435 \\
\hline $\mathbf{X 2}$ & 0,257 & 0,102 & 0,258 & 2,518 & 0,014 \\
\hline $\mathbf{X 3}$ & $-0,033$ & 0,144 & $-0,027$ & $-0,228$ & 0,820 \\
\hline $\mathbf{X 4}$ & 0,153 & 0,109 & 0,182 & 1,403 & 0,164 \\
\hline $\mathbf{X 5}$ & $-0,078$ & 0,062 & $-0,142$ & $-1,271$ & 0,207 \\
\hline
\end{tabular}

Berdasarkan pada hasil analisis yang telah dilakukan dengan menggunakan program SPSS yang tercantum pada tabel 2 di atas, maka persamaan regresi yang terbentuk adalah sebagai berikut:

$Y=2,219+0,092 \mathrm{X} 1+0,257 \mathrm{X} 2-0,033 \mathrm{X3}+0,153 \mathrm{X} 4-$ $0,078 \times 5+\mathrm{e}$

Berdasarkan persamaan (2) di atas, dapat dijabarkan sebagai berikut:

1. Konstanta sebesar 2,219 artinya bila tidak ada kelima variabel bebas yang memengaruhi variabel keputusan pembelian konsumen online, maka variabel keputusan pembelian konsumen online akan bertambah sebesar 2,219 .

2. Koefisien regresi pada variabel logistik digital sebesar 0,092 adalah positif, artinya bila terjadi penambahan 1 satuan variabel logistik digital, dimana factor-faktor lain tetap konstan, maka akan meningkatkan faktor logistik digital sebesar 0,092. Ini berarti variabel logistik digital memiliki kontribusi sebesar 0,092 terhadap variabel keputusan pembelian konsumen online.

3. Koefisien regresi pada variabel integritas online sebesar 0,257 adalah positif, artinya bila terjadi penambahan 1 satuan variabel integritas online dan faktor-faktor lain tetap konstan, maka faktor integritas online meningkat sebesar 0,257. Artinya variabel integritas online memiliki kontribusi sebesar 0,257 terhadap variabel keputusan pembelian konsumen online.

4. Koefisien regresi pada variabel desain website sebesar 0,033 adalah negatif, artinya bila terjadi penambahan 1 satuan variabel desain website, dimana faktor-faktor lain tetap konstan, maka akan mengurangi faktor desain website sebesar 0,033. Artinya variabel desain website memiliki kontribusi negatif sebesar 0,033 terhadap variabel keputusan pembelian konsumen online.

5. Koefisien regresi pada variabel pemasaran digital sebesar 0,153 adalah positif, artinya bila terjadi penambahan 1 satuan variabel pemasaran digital, dimana faktor-faktor lain tetap konstan, maka akan meningkatkan faktor pemasaran digital sebesar 0,153. Ini berarti variabel pemasaran digital memiliki kontribusi sebesar 0,153 terhadap variabel keputusan pembelian konsumen online.

6. Koefisien regresi pada variabel alternatif kontak vendor/merek sebesar 0,078 adalah negatif, artinya bila terjadi penambahan 1 satuan variabel alternatif kontak vendor/merek, dimana faktor-faktor lain tetap konstan, maka akan mengurangi faktor alternatif kontak vendor/merek sebesar 0,078. Ini berarti variabel alternatif kontak vendor/merek memiliki kontribusi negatif sebesar 0,078 terhadap variabel keputusan pembelian konsumen online.

\section{A. Hasil Uji Koefisien Determinasi}

Koefisien determinasi digunakan untuk mengukur seberapa jauh kemampuan model yang digunakan dalam penelitian dapat menerangkan varian variabel terikat. Hasil uji koefisien determinasi penelitian ini dapat dilihat pada tabel 2 berikut:

\begin{tabular}{crrr}
\multicolumn{4}{c}{ Tabel 3. Hasil Uji Koefisien Determinasi } \\
\hline $\mathbf{R}$ & $\boldsymbol{R}$ Square & $\begin{array}{l}\text { Adjusted } \\
\text { R Square }\end{array}$ & $\begin{array}{r}\text { Std. } \text { Error of } \\
\text { The Estimate }\end{array}$ \\
\hline 0,783 & 0,613 & 0,592 & 0,50971 \\
\hline
\end{tabular}

Di dalam analisis regresi ini, total $\mathrm{R}$ square adalah $61,3 \%$, dengan adjusted $\mathrm{R}$ square 59,2\%. Hal ini menunjukkan bahwa variabel keputusan pembelian konsumen dapat dijelaskan oleh kelima variabel bebas, yaitu: logistik digital, integritas online, pemasaran digital, alternatif kontak vendor/merek, dan desain website sebesar $61,3 \%$, sedangkan sisanya sebesar $38,7 \%$ fenomena keputusan pembelian konsumen online merupakan faktor lain di luar 5 faktor yang digunakan di dalam penelitian ini.

\section{B. Pengujian Hipotesis}

Berdasarkan Tabel 4, diperoleh $\mathrm{F}$ hitung sebesar 2,373 dan nilai signifikansi sebesar 0,045 dimana $<0,05$. Nilai $F$ hitung 2,373 juga memiliki nilai $>2,31$ yang merupakan $F$ tabel. Maka dapat dikatakan secara keseluruhan, kelima variabel bebas di dalam model penelitian ini memiliki pengaruh untuk menentukan keputusan pembelian konsumen. Oleh karena itu hipotesa yang digunakan di dalam penelitian ini secara keseluruhan dapat diterima.

Tabel 4. Hasil Uji F Statistik ANOVA

\begin{tabular}{lrrrrr}
\hline Model & $\begin{array}{c}\text { Sum of } \\
\text { Squares }\end{array}$ & Df & $\begin{array}{c}\text { Mean } \\
\text { Square }\end{array}$ & F & Sig. \\
\hline Regression & 4,410 & 5 & 0,882 & 2,373 & 0,045 \\
\hline Residual & 39,944 & 94 & 0,372 & & \\
\hline Total & 39,354 & 99 & & & \\
\hline
\end{tabular}

Berdasarkan Tabel 1, dari 5 variabel bebas yang dimasukkan ke dalam model penelitian terdapat 1 variabel dengan tingkat signifikansi sebesar $5 \%(\leq 0,05)$ atau dapat dikatakan berpengaruh signifikan terhadap keputusan pembelian konsumen, yaitu variabel X2/integritas online. Hal ini dapat dilihat dari signifikansi untuk variabel tersebut sebesar 0,014 $(<0,05)$, sedangkan untuk variabel-variabel lainnya memiliki nilai signifikansi $>0,05$ atau tidak memiliki pengaruh yang signifikan terhadap Keputusan pembelian konsumen.

\section{Interpretasi Hasil}

Ketentuan pengambilan keputusan hipotesis diterima atau ditolak didasarkan pada besarnya nilai signifikansi. Jika nilai 
signifikansi $\leq 0,05$ maka hipotesis akan diterima, sedangkan jika nilai signifikansi >0,05, maka hipotesis akan ditolak. Berikut ini merupakan hasil perhitungannya:

1. Logistik Digital (X1)

Oleh karena Logistik Digital memiliki nilai signifikansi sebesar 0,435, dimana >0,05 maka dapat ditarik kesimpulan bahwa Hipotesis "Logistik Digital memiliki pengaruh positif terhadap Keputusan Pembelian Konsumen Online", ditolak.

2. Integritas Online (X2)

Oleh karena Integritas Online memiliki nilai signifikansi sebesar 0,014, dimana $<0,05$ maka dapat ditarik kesimpulan bahwa Hipotesis "Integritas Online memiliki pengaruh positif terhadap Keputusan Pembelian Konsumen Online", diterima.

3. Desain Website (X3)

Oleh karena Desain Website memiliki nilai signifikansi sebesar 0,820, dimana >0,05 maka dapat ditarik kesimpulan bahwa Hipotesis "Desain Website memiliki pengaruh positif terhadap Keputusan Pembelian Konsumen Online", ditolak.

4. Pemasaran Digital (X4)

Oleh karena Pemasaran Digital memiliki nilai signifikansi sebesar 0,164, dimana >0,05 maka dapat ditarik kesimpulan bahwa Hipotesis "Pemasaran Digital memiliki pengaruh positif terhadap Keputusan Pembelian Konsumen Online", ditolak.

5. Alternatif Kontak Vendor/Merek (X5)

Oleh karena Alternatif Kontak Vendor/Merek memiliki nilai signifikansi sebesar 0,207, dimana >0,05 maka dapat ditarik kesimpulan bahwa Hipotesis "Alternatif Kontak Vendor/Merek memiliki pengaruh positif terhadap Keputusan Pembelian Konsumen Online”, ditolak.

\section{Pembahasan}

Dalam penelitian ini, responden terkait konsumen belanja online di online marketplace lebih didominasi oleh wanita, sedangkan dari rentang usia, mayoritas responden didominasi oleh mereka yang berusia 21-25 tahun. Adapun rerata responden berbelanja online dalam 1 bulan didominasi oleh mereka yang berbelanja sebanyak 1-3x. Hal ini dapat dijadikan pertimbangan oleh perusahaan dalam menentukan strategi yang lebih mengarah kepada pemenuhan kebutuhan untuk konsumen berusia 16-30 tahun, yang mendominasi konsumen belanja online di online marketplace.

Berdasarkan hasil analisis regresi, diperoleh nilai koefisien sebesar 0,092 untuk variabel logistik digital yang ditunjukkan dengan hasil pengujian signifikansi sebesar 0,435 . Hal ini menunjukkan bahwa logistik digital tidak memiliki pengaruh yang signifikan terhadap keputusan pembelian konsumen.

Sebagian besar perusahaan online marketplace cenderung menawarkan manfaat dari jasa pengiriman yang sama, manfaat tersebut dianggap penting oleh konsumen, yaitu: harga pengiriman yang bersaing, kemudahan dalam pengembalian produk, dan pengiriman same-day service. Kondisi ini membuat faktor dari logistik digital tidak memiliki pengaruh terhadap keputusan pembelian konsumen online.
Namun, jika bagian di dalam logistik digital ke depan memiliki perbedaan value yang ditawarkan oleh masingmasing perusahaan, maka faktor logistik digital dapat mempengaruhi keputusan pembelian konsumen online. Tidak dapat dipungkiri, bahwa logistik digital merupakan bagian fundamental dari online marketplace, dimana rerata responden juga mengatakan setuju bahwa logistik digital merupakan faktor yang penting, namun tidak secara langsung memengaruhi keputusan pembelian konsumen.

Berdasarkan hasil analisis regresi, diperoleh nilai koefisien sebesar 0,257 untuk variabel integritas online yang ditunjukkan dengan hasil pengujian signifikansi sebesar 0,014 . Hal ini menunjukkan bahwa integritas online memiliki pengaruh yang signifikan terhadap keputusan pembelian konsumen online. Temuan ini sejalan dengan pendapat bahwa integritas online merupakan salah satu faktor penting yang dapat memunculkan keinginan konsumen menggunakan layanan online marketplace.

Faktor yang paling dominan pada penelitian ini terkait integritas online adalah jaminan keamanan dalam transaksi dan pilihan alternatif pembayaran yang beragam, dimana $>90 \%$ responden mengatakan setuju dan sangat setuju bahwa kedua faktor tersebut merupakan faktor yang penting.

Pentingnya keamanan dalam melakukan transaksi di online marketplace menjadi sangat penting dikarenakan teknologi pembayaran digital masih merupakan teknologi yang baru di Indonesia, dimana penetrasi kartu kredit di Indonesia baru sebesar $2,4 \%$ dan pemilik mobile money account sebesar $3,1 \%$. Secara keseluruhan, hanya sekitar $48 \%$ populasi yang memiliki akun bank dan sisanya masih mengandalkan pembayaran secara tunai [2].

Kondisi ini membuat konsumen yang ingin berbelanja di online marketplace, dan melakukan pembayaran secara cashless. Kepercayaan diperlukan tidak hanya terhadap perusahaan, namun juga kepada internet sebagai tempat untuk melakukan transaksi.

Berdasarkan hasil analisis regresi, diperoleh nilai koefisien sebesar -0,033 untuk variabel desain website yang ditunjukkan dengan hasil pengujian signifikansi sebesar 0,820. hal ini menunjukkan bahwa desain website tidak memiliki pengaruh yang signifikan terhadap keputusan pembelian konsumen online. Tanpa kemampuan untuk mencoba produk, maka risiko di dalam pembelian produk akan meningkat. Hal ini juga ditunjukkan dengan kecenderungan konsumen online di Indonesia yang masih memerlukan kontak langsung dengan produk untuk dapat merasakan kualitas dari produk tersebut.

Hal tersebut dibuktikan dengan tingginya kekhawatiran responden di dalam penelitian dengan mayoritas responden mengatakan bahwa kesesuaian produk, visualisasi, dan kemudahan mencari produk yang dicari memiliki skor kepentingan yang lebih tinggi jika dibandingkan dengan tampilan website yang menarik itu sendiri. Kondisi tersebut menunjukkan hubungan yang negatif antara desain website dengan keputusan pembelian konsumen. Semakin tinggi tingkat kekhawatiran konsumen, maka keputusan pembelian konsumen online akan terpengaruh negatif. 
Berdasarkan hasil analisis regresi, diperoleh nilai koefisien sebesar 0,153 untuk variabel Pemasaran Digital yang ditunjukkan dengan hasil pengujian signifikansi sebesar 0,164 . Hal ini menunjukkan bahwa pemasaran digital tidak memiliki pengaruh yang signifikan terhadap keputusan pembelian konsumen. Faktor harga dan promosi penjualan masih memegang peran yang lebih dominan bagi konsumen sebelum menentukan melakukan pembelian atau mengunjungi suatu website.

Hasil tersebut ditunjukkan dengan lebih tingginya faktor promosi harga yang lebih murah dari toko fisik serta program diskon atau bundling dibandingkan dengan program pemasaran digital lainnya, seperti loyalitas konsumen dan personalisasi konten.

Berdasarkan hasil analisis regresi, diperoleh nilai koefisien sebesar -0,078 untuk variabel alternatif kontak vendor/merek yang ditunjukkan dengan hasil pengujian signifikansi sebesar 0,207. Hal ini menunjukkan bahwa alternatif kontak vendor/merek tidak memiliki pengaruh yang signifikan terhadap keputusan pembelian konsumen.

Meskipun mayoritas konsumen setuju bahwa penting bagi perusahaan membuka berbagai alternatif kontak, namun cenderung ragu-ragu apakah penting bagi perusahaan membuka akun di sosial media seperti Twitter dan Facebook. Mayoritas konsumen lebih memilih jika memang diperlukan membuka akun sosial media perusahaan lebih baik di Instagram. Tidak dapat dipungkiri bahwa aktifnya perusahaan di sosial media telah turut serta menjadi alat pemasaran digital.

Di dalam keputusan pembelian konsumen online, terdapat beberapa indikator di dalamnya seperti: loyalitas konsumen online terhadap satu merek, tingkat keragu-raguan konsumen berbelanja online, dan rasa percaya terhadap merek.

Berdasarkan tingkatan di atas, maka penting bagi perusahaan untuk mengetahui tingkat loyalitas konsumen online terhadap satu merek, tingkat keragu-raguan konsumen berbelanja online, dan rasa percaya terhadap merek. Mengetahui tingkat loyalitas konsumen dapat membantu perusahaan untuk memengaruhi keputusan konsumen ketika melakukan evaluasi dengan alternatif perusahaan online marketplace lain. Mengetahui tingkat keragu-raguan konsumen terhadap berbelanja online akan berpengaruh pada tahap konsumen menentukan pilihan, apakah akan membeli secara online atau di toko fisik. Mengetahui pentingnya rasa percaya terhadap merek dari konsumen akan berpengaruh pada tahap ketika konsumen menentukan pilihan perusahaan online marketplace dimana yang akhirnya dipilih oleh konsumen.

Konsumen online marketplace di Indonesia saat ini cenderung agak loyal terhadap satu perusahaan ketika berbelanja secara online di online marketplace, dengan ratarata konsumen memilih agak setuju terkait loyalitas terhadap satu merek. Sedangkan mayoritas konsumen online marketplace di Indonesia saat ini tidak ragu ketika berbelanja di online marketplace, namun tetap menganggap bahwa kredibilitas perusahaan penyedia jasa layanan online marketplace sebagai faktor yang penting.

\section{KESIMPULAN}

Hasil pengolahan data menunjukkan dari lima variabel bebas yang diteliti, yaitu, logistik digital, integritas online, desain website, pemasaran digital, dan alternatif kontak vendor/merek; hanya variabel integritas online yang memiliki pengaruh signifikan terhadap variabel terikat keputusan pembelian konsumen online. Hal ini didukung oleh uji t signifikansi yang hasilnya $<0,05$ untuk variabel integritas online, sedangkan variabel yang lain memiliki hasil $>0,05$.

Logistik digital tidak memiliki dampak langsung terhadap keputusan pembelian konsumen, karena sebagian besar perusahaan online marketplace cenderung menawarkan manfaat dari jasa pengiriman yang sama dan manfaat tersebut dianggap penting oleh konsumen. Hal ini ditunjukkan dengan hasil uji t signifikansi yang hasilnya 0,435 dimana $>0,05$.

Desain website tidak memiliki dampak langsung terhadap keputusan pembelian konsumen, karena perilaku konsumen di Indonesia lebih mengutamakan kesesuaian produk, kemudahan mencari produk, jika dibandingkan dengan desain tampilan website tersebut sendiri. Hal ini ditunjukkan dengan hasil uji t signifikansi yang hasilnya 0,820 dimana $>0,05$.

Pemasaran digital tidak memiliki dampak langsung terhadap keputusan pembelian konsumen, karena bagi konsumen online di Indonesia, faktor promosi masih memegang peranan yang lebih penting jika dibandingkan dengan pengembangan program loyalitas konsumen dan personalisasi konten. Selain itu, promosi melalui media konvensional masih memegang peranan yang lebih besar dalam memengaruhi konsumen dibandingkan dengan digital. Hal ini ditunjukkan dengan hasil uji t signifikansi yang hasilnya 0,164 dimana $>0,05$

Alternatif kontak vendor/merek tidak memiliki dampak langsung terhadap keputusan pembelian konsumen, meskipun mayoritas konsumen setuju bahwa penting bagi perusahaan agar membuka berbagai alternatif kontak, namun konsumen cenderung ragu-ragu apakah penting bagi perusahaan membuka akun sosial media. Hal ini ditunjukkan dengan hasil uji t signifikansi yang hasilnya 0,207 dimana $>0,05$.

Integritas online memiliki dampak langsung terhadap keputusan pembelian konsumen, karena pentingnya keamanan dalam melakukan transaksi di online marketplace terlebih penetrasi pembayaran digital masih merupakan teknologi yang baru di Indonesia, dimana penetrasinya baru sekitar 10\% di Indonesia. Hal ini ditunjukkan dengan hasil uji $\mathrm{t}$ signifikansi yang hasilnya 0,014 dimana $<0,05$.

Faktor yang paling dominan di dalam penelitian ini terkait integritas online adalah jaminan keamanan dalam transaksi dan pilihan alternatif pembayaran yang beragam, dimana $>90 \%$ responden mengatakan setuju dan sangat setuju bahwa kedua faktor tersebut merupakan faktor yang penting dalam memengaruhi keputusan pembelian secara online.

Berdasarkan interpretasi hasil penelitian yang telah dijelaskan di atas, maka dapat ditarik beberapa masukan yang dapat bermanfaat untuk diterapkan oleh perusahaan online marketplace di masa yang akan datang untuk dapat mendorong konsumen berbelanja di platform yang dimiliki, yaitu dengan memfokuskan strategi pada pengembangan 
integritas online. Dikarenakan variabel integritas online memiliki pengaruh signifikan terhadap keputusan pembelian konsumen online.

Integritas online dapat ditingkatkan oleh perusahaan dengan beberapa cara, diantaranya memperluas metode pembayaran menjadi lebih beragam, meningkatkan tingkat keamanan transaksi pembayaran di dalam platform, serta memastikan keamanan data-data pribadi konsumen di dalam platform. Perusahaan dapat berkolaborasi dengan beberapa perusahaan Fintech, berbagai rekanan perbankan, tidak hanya bank besar namun juga bank daerah untuk memperluas jaringan pembayaran, dan juga pengembangan sistem untuk mempercepat proses pembayaran.

Didukung dengan hasil survey, 90\% responden mengatakan bahwa penting bagi perusahaan untuk memperluas metode pembayaran, maka metode pembayaran yang disediakan oleh perusahaan perlu diperluas dengan membuka sistem pembayaran yang lebih beragam, seperti COD, O2O, E-Cash dari perbankan terpercaya.

Sebanyak 90\% responden mengatakan bahwa sistem keamanan dalam bertransaksi online penting bagi mereka, maka memperkuat keamanan dalam bertransaksi di dalam platform penting dilakukan oleh perusahaan. Perusahaan perlu memperkuat sistem keamanan pembayaran perusahaan agar tidak mudah dirusak oleh pihak yang tidak bertanggungjawab. Cara lain adalah bekerja sama dengan pihak ketiga untuk menguji jaminan keamanan platform.

\section{REFERENSI}

[1] Criteo. (2016). ECommerce Industry Outlook.

[2] We Are Social \& Hootsuite. (2020). Digital 2020. Global Digital Insights. Diakses dari: https://datareportal.com/ reports/digital-2020-global-digital-overview

[3] Research, D. G. (2015). E-commerce In Asia: Bracing for Digital Disruption. Diakses dari: http://go.dbs.com/ research

[4] Statista. (2020). Outlook of e-commerce Indonesia. Diakses dari: https://www.statista.com/outlook/243/ 120/e-commerce/indonesia

[5] Choo, S. (2016). Indonesia Digital Transformation Outlook Briefing 2016. ASEAN \& Indonesia e-commerce Outlook.

[6] Ahmad, S.Z., Abu Bakar, A.R., Faziharudean, T.M. \& Zaki, K.A.M. (2015). An Empirical Study of Factors Affecting e-Commerce Adoption among Small- and Medium-Sized Enterprises in a Developing Country: Evidence from Malaysia. Information Technology for Development, Vol. 21(4), pp. 555-572. Diakses dari: https://doi.org/10.1080/02681102.2014.899961

[7] Cyr, D. (2008). Modeling Web Site Design Across Cultures: Relationships to Trust, Satisfaction, and ELoyalty. Journal of Management Information Systems, Vol. 24(4), pp. 47-72. Diakses dari: https://doi.org/10.2753/MIS0742-1222240402
[8] Hoffman, D.L., Novak, T.P. \& Peralta, M. (1999). Building Consumer Trust in Online Environments: The Case for Information Privacy. Communications of the ACM, Vol. 42, pp. 80-85.

[9] Lowry, P.B., Vance, A., Moody, G., Beckman, B. \& Read, A. (2008). Explaining and Predicting the Impact of Branding Alliances and Web Site Quality on Initial Consumer Trust of E-Commerce Web Sites. Journal of Management Information Systems, Vol. 24(4), pp. 199224. Diakses dari: https://doi.org/10.2753/MIS07421222240408

[10] Kim, E.Y. \& Kim, Y. (2004). Predicting Online Purchase Intentions for Clothing Products. European Journal of Marketing, Vol. 38(7), pp. 883-897. Diakses dari: https://doi.org/10.1108/03090560410539302

[11] Kim, C., Galliers, R.D., Shin, N., Ryoo, J.H. \& Kim, J. (2012). Factors Influencing Internet Shopping Value and Customer Repurchase Intention. Electronic Commerce Research and Applications, Vol. 11(4), pp. 374-387. Diakses dari https://doi.org/10.1016/j.elerap.2012.04.002

[12] Gümüş, M., Li, S., Oh, W. \& Ray, S. (2013). Shipping Fees or Shipping Free? A Tale of Two Price Partitioning Strategies in Online Retailing. Production and Operations Management, Vol. 22(4), pp. 758-776. Diakses dari https://doi.org/10.1111/j.19375956.2012.01391.x

[13]Zhang, L. \& Zhang, Y. (2013). A Comparative Study of Environmental Impacts of Two Delivery Systems in the Business-to-Customer Book Retail Sector. Journal of Industrial Ecology, Vol. 17(3), pp. 407-417. Diakses dari: https://doi.org/10.1111/j.1530-9290.2012.00570.x

[14] General, M. \& Singh, B. (2014). E-Commerce Logistics: The New Wave. International Journal of Multidisciplinary Approach and Studies, Vol. 28(123), pp. 101-120. Diakses dari: https://doi.org/10.1016/ S0123-5923(12)70207-3

[15] Kim, C., Tao, W., Shin, N. \& Kim, K.S. (2010). An Empirical Study of Customers' Perceptions of Security and Trust in E-Payment Systems. Electronic Commerce Research and Applications, Vol. 9(1), pp. 84-95. Diakses dari: https://doi.org/10.1016/j.elerap.2009.04.014

[16] Roca, J. C., García, J.J. \& de la Vega, J.J. (2009). The Importance of Perceived Trust, Security and Privacy in Online Trading Systems. Information Management and Computer Security, Vol. 17(2), pp. 96-113. Diakses dari: https://doi.org/10.1108/09685220910963983

[17] Rau, A. (2014). E-Payments in Emerging Markets. Journal of Payments Strategy \& Systems. First Data Corporation.

[18] Diamond, J. \& Diamond, E. (2010). Contemporary Visual Merchandising Environmental Design (5 Edition). Pearson.

[19] Martins, P., Pereira, M., Azevedo, S. G., Rui A. L. M. \& Lucas, J. (2014). Fashion Design and Visual Merchandising Attributes in E-commerce. International 
Journal of Management Cases, Vol. 14(4). https://doi.org/10.5848/apbj.2012.00094

[20]Eid, R. \& El-Gohary, H. (2013). The Impact of EMarketing Use on Small Business Enterprises' Marketing Success. Service Industries Journal, Vol. 33(1), pp. 3150. Diakses dari: https://doi.org/10.1080/ 02642069.2011 .594878

[21] Jiang, Y. \& Liu, Y. (2012). Optimization of Online Promotion: a Profit-Maximizing Model Integrating Price Discount and Product Recommendation. International Journal of Information Technology and Decision Making, Vol. 11(5), pp. 961-982. Diakses dari: https://doi.org/10.1142/S0219622012500289

[22] Park, J. K., Chung, H. E. \& Rutherford, B. (2011). Social Perspectives of E-Contact Center for Loyalty Building. Journal of Business Research, Vol. 64(1), pp. 34-38. Diakses dari: https://doi.org/10.1016/j.jbusres. 2009.09.017

[23] Park, F. K., Doreen Chung, T. L., Gunn, F. \& Rutherford, B. (2015). The Role of Listening in E-Contact Center Customer Relationship Management. Journal of Services Marketing, Vol. 29(1), pp. 49-58. Diakses dari: https://doi.org/10.1108/JSM-02-2014-0063

[24]Fang, Y., Qureshi, I., Sun, H., McCole, P., Ramsey, E., \& Lim, K.H. (2014). Trust, Satisfaction, and Online Repurchase Intention: The Moderating Role of Perceived Effectiveness of E-Commerce Institutional Mechanisms. MIS Quarterly: Management Information Systems, Vol. 38(2), pp. 407-427. Diakses dari: https://doi.org/10.25300/MISQ/2014/38.2.04

[25] Makelainen, S. (2006). From B2C to C2C E-commerce. Helsingfors Universitet, University of Helsinki.
[26] Forrester. (2016). Retailers Must Seize The Marketplace Opportunity [Slide].

[27] Kemp, S. (2018). Digital in 2018 in Southeast Asia. We Are Social. Diakses dari: https://doi.org/ 10.1109/EMBC.2013.6610226

[28] Hallberg, G. \& Krysen, S. (2015). Factors Influencing the Consumer Purchase Decision Within E-Commerce in Emerging Markets - A Study Conducted in Poland. Linnaeus University.

[29] Bahar, J. (2017). E-Commerce Industry in Indonesia. Indonesia GATES ICT Reseller Channel Summit 2017.

[30] Strauss, J., \& Frost, R. (2011). E-Marketing. Prentice Hall.

[31] Wen, C., Prybutok, V. R., \& Xu, C. (2011). An Integrated Model for Customer Online Repurchase Intention. Journal of Computer Information Systems, Vol. 52(1), pp. 14-23. Diakses dari: https://doi.org/10.1080/ 08874417.2011.11645518

[32] Sultan, M.U. \& Uddin, M.D.N. (2011). Consumers' Attitude Towards Online Shopping [Master Thesis]. Högskolan på Gotland.

[33] Sreerekha, T., Saranya, R., Prabhu, V.S.. (2019). Consumer Behaviour in Online Shopping. International Journal of Trend in Scientific Research and Development, Vol. 3(5), pp. 460-464. Diakses dari: https://doi.org/10.31142/ijtsrd26354

[34]Burney, A. \& Saleem, H. (2008). Inductive And Deductive Research Approach. Karachi, Pakistan: University of Karachi

[35] Bryman, A. \& Bell, E. (2011). Business Research Methods (O. Oxford (ed.); 3 Edition). OUP Oxford.

[36] Universitas Brawijaya. (2015). Metode Penelitian: Populasi dan Sampel. Brawijaya University. 